\section{Kemampuan Pemecahan Masalah Peserta Didik Pada Model Problem Based Learning (PBL) Kelas X SMA Negeri 3 Makassar}

\author{
Anisatya Amaliah \\ Muh Wiharto \\ Muhiddin P
}

\begin{abstract}
Abstrak. Penelitian ini bertujuan untuk mengetahui pengaruh model Problem Based Learning (PBL) terhadap kemampuan pemecahan masalah siswa pada pelajaran perubahan iklim di kelas X SMA Negeri 3 Makassar. Penelitian ini merupakan penelitian eksperimen semu dengan desain pre-test-post-test control group design dan terdiri dari dua kelompok yaitu kelompok eksperimen dan kelompok kontrol. Populasi dalam penelitian ini adalah siswa kelas X SMA Negeri 3 Makassar dan pemilihan kedua kelompok menggunakan teknik random sampling. Kelompok yang dipilih sebagai sampel penelitian adalah X MIA 1 sebagai kelompok eksperimen dan X MIA 5 sebagai kelompok kontrol. Jenis instrumen penelitian yang digunakan adalah pilihan ganda dan tes deskriptif. Data kemampuan pemecahan masalah dikumpulkan dengan menggunakan tes deskriptif yang diberikan sebelum dan sesudah perlakuan kemudian dianalisis menggunakan statistik deskriptif dan statistik inferensial. Statistik deskriptif digunakan untuk mendeskripsikan kemampuan pemecahan masalah siswa dan statistik inferensial digunakan untuk menguji hipotesis dengan analisis kovarian. Hasil penelitian menunjukkan bahwa nilai signifikan antara PBL dan kemampuan pemecahan masalah siswa adalah $0,000(\alpha<0,05)$ dan nilai signifikan antara PBL dengan hasil belajar adalah 0,000 $(\alpha<0,05)$. Berdasarkan hasil yang diperoleh, dapat disimpulkan bahwa penerapan PBL dalam proses pembelajaran berpengaruh terhadap kemampuan pemecahan masalah dan perubahan iklim pada siswa kelas X SMA Negeri 3 Makassar.
\end{abstract}

Kata Kunci: problem based learning (PBL), kemampuan pemecahan masalah

\section{Pendahuluan}

Perkembangan pada era globalisasi dengan kemajuan teknologi memberikan dampak yang besar terhadap perkembangan dan kemajuan suatu bangsa. Hal ini merupakan suatu tantangan bagi bangsa untuk mampu bersaing dengan bangsa lain. Usaha yang diperlukan untuk mampu bersaing dengan bangsa lain adalah meningkatkan kualitas dan potensi sumber daya manusia melalui pendidikan yakni untuk mempersiapkan peserta didik dalam memasuki abad XXI. Trilling dan Fadel (2010) menyatakan bahwa untuk dapat menghadapi tantangan abad ke-21 seseorang harus memiliki keterampilan sebagai berikut 1) Berfikir kritis dan mampu memecahkan masalah 2) Komunikasi dan kolaborasi, 3) Kreatifitas dan inovasi, 4) Informasi literasi, 5) Media literasi, 6) ICT literasi ,7) Flexibilitas dan adaptasi. National Education Association (2002) berpendapat bahwa terdapat 18 macam $21^{\text {st }}$ Century Skills yang perlu dibekalkan pada setiap individu, dimana salah satunya ialah Learning and Innovation

\section{Biology Teaching and Learning}

p-ISSN $2621-5527$
e-ISSN $2621-5535$

Abstract. This research aimed to determine the effect of Problem Based Learning (PBL) model towards student's problem solving ability in climate change lesson of grade $X$ students Senior High School 3 Makassar. This was a quasiexperimental research with pre-testpost test control group design and

consist of two groups which were experimental group and control group. The population of this study is grade $X$ students of Senior High School 3

Makassar and the two groups were chosen by using random sampling

technique. The groups chosen as the research sample is X MIA 1 as the experimental group and X MIA 5 as the control group. Type of research instrument that used were essay test and multiple choice. Data of problemsolving ability was collected by essay test that given before and after treatment and then analyzed by using descriptive statsistics and inferential statistics. Descriptive statistic used to

describe student's problem solving ability and inferential statistics used to hypothesis test by analysis of covariance. The results shows that the

significant value between PBL and student's problem solving ability was

$0,000(\alpha<0,05)$ and the significant value between $P B L$ and learning outcomes was 0,000 $(\alpha<0,05)$. Based on the result obtained, it can be coclude that the application of PBL on learning process affect problem solving ability and Climate Change lesson of grade X students Senior High School 3 Makassar.

Keywords: problem-based learning $(P B L)$, problem solving ability

Anisatya Amaliah Universitas Negeri Makassar Indonesia

Muh Wiharto

Universitas Negeri Makassar Indonesia

Muhiddin Palennari

Universitas Negeri Makassar Indonesia 
yang terdiri dari 4 aspek, yaitu critical thinking (berpikir kritis), communication (komunikasi), collaboration (kolaborasi atau kerjasama), dan creativity (kreativitas).

Pendidikan digunakan dalam waktu jangka panjang, namun pendidikan diindonesia masih terkendala dalam kualitas pendidikan. Wijaya (2016) berpendapat bahwa Berbagai usaha telah dilakukan dalam perbaikan mutu pendidikan yaitu dengan menggunakan kurikulum 2013. Pemberlakuan kurikulum 2013 yang mengharuskan dunia pendidikan perlu melakukan pembaharuan terus agar tidak ketinggalan jaman sejalan dengan perkembangan abad 21, yakni teknologi informasi, jaringan digital, dan literasi. Namun hal itu, tampaknya belum mencapai hasil yang optimal. kurikulum diciptakan agar peserta didik mampu meningkatkan prestasi belajarnya serta aktif dalam setiap kegiatan pembelajaran, namun pemberlakuan kurikulum 2013 ini masih kurang implementasinya.

Sekolah SMA Negeri 3 Makassar meski telah menggunakan kurikulum 2013, proses pembelajaran tidak serta merta menjadi ideal seperti yang diharapkan. Hasil observasi awal menunjukkan bahwa guru masih menjadi pusat proses pembelajaran dan keaktifan peserta didik dalam pembelajaran yang masih rendah. Keaktifan peserta didik selama kegiatan pembelajaran merupakan salah satu indikator adanya keinginan peserta didik untuk belajar akan tetapi peran serta peserta didik dalam proses pembelajaran di sekolah masih kurang yakni hanya sedikit yang menunjukkan keaktifan berpendapat dan bertanya. Pendapat dan pertanyaan yang dibuat peserta didik juga belum mengarah kepada pemecahan masalah yang berkaitan dengan materi yang dipelajari.

Dapat dilihat bahwa proses pembelajaran yang masih rendah dan keaktifan yang masih kurang, dimana kriteria ketuntasan minimum (KKM) 75 sedangkan nilai rata-rata peserta didik masih jauh dari nilai ketuntasan rata-rata nilai yang didapatkan yaitu 58,5. Rendahnya hasil belajar peserta didik tidak lepas dari kemampuan peserta didik dalam memahami pembelajaran yang diajarakan. Hal tersebut telah dirumuskan dalam Permendikbud No.64, tahun 2013 tentang kompetensi kelas X pada Kurikulum 2013 (K13) untuk mata pelajaran biologi SMA-MA (Permendikbud, 2013).

UNESCO (Tilaar, 1999) juga menerangkan bahwa model pembelajaran meliputi "learning to know, learning to do, learning to be, and learning to live together". Jadi siswa bukan hanya duduk diam dan mendengarkan, tetapi siswa harus diberdayakan agar siswa mau serta mampu berbuat untuk memperkaya pengalaman belajarnya (learning to do); mampu berinteraksi dengan lingkungannya dan menuntut mereka untuk memahami pengetahuan yang berkaitan dengan dunia sekitarnya (learning to know); sehingga dari interaksi tersebut diharapkan siswa mampu membangun jati diri (learning to be); dan dengan adanya kesempatan untuk berinteraksi dengan berbagai individu atau kelompok yang bervariasi akan tercipta kepribadian untuk memahami kemajemukan serta melahirkan sikap toleran positif terhadap keanekaragaman individu (learning to live together).

Salah satu model pembelajaran yang dapat mengembangkan kemampuan berpikir kritis dalam mpemecahan masalah yakni Model Problem Based Learning (PBL). PBL merupakan pembelajaran yang dapat diterapkan untuk mencapai kompetensi di era pengetahuan memiliki ciri-ciri pembelajaran dimulai dengan pemberian masalah (Palennari, 2016). Masalah memiliki konteks dengan dunia nyata, peserta didik secara berkelompok aktif merumuskan masalah dan mengidentifikasi kesenjangan pengetahuan mereka, mempelajari dan mencari sendiri materi yang terkait dengan masalah dan melaporkan solusi dari masalah (Anggraeni \& Herdiman, 2018).

PBL memberikan banyak manfaat bagi peserta didik untuk mengembangkan kemampuan berpikir tingkat tinggi seperti berpikir kritis dan memecahkan masalah. PBL didasari bahwa belajar bukan hanya proses menghafal konsep atau mengemukakan fakta tetapi proses interaksi

antara individu dengan lingkungannya PBL juga dapat mengembangkan keterampilan yang diperlukan di era pengetahuan (Bahri, 2017). Metode pembelajaran yang digunakan antara lain: (1) ceramah, (2) diskusi, (3) presentasi, (4) tanya jawab, (5) penugasan, (6) kerja kelompok, dan (7) problem solving (Palennari dkk, 2015).

Pendidik lebih banyak memfasilitasi, guru tidak menyajikan konsep yang sudah jadi. 
Namun melalui kegiatan pemecahan masalah peserta didik dibawa ke arah menemukan konsep sendiri. Startegi yang dapat dilakukan dalam pembelajaran yang menunjang pendekatan learner centered adalah problem based laeraning. PBL dikembangkan dalam membantu peserta didik untuk mengenmbangkan keterampilan intelektual dan belajar dalam berbagai peran orang dewasa melalui pelibatan dalam pengalaman nyata (Fallis, 2013).

Kono (2016), menyatakan bahwa PBL merupakan salah satu model pembelajaran yang menuntut aktivitas mental peserta didik untuk memahami suatu konsep pembelajaran, melalui situasi dan masalah yang disajikan pada awal pembelajaran. Proses pembelajaran tidak lagi terpusat pada guru, melainkan pada masing masing peserta didik. Tujuan PBL menurut HmeloSilver (2004) adalah (1) membangun dasar-dasarpengetahuan yang luas dan fleksibel (2) mengembangkan keterampilan pemecahan masalah yang efektif; (3) mengembangkan selfdirected dan keterampilan belajar sepanjang hayat, (4) menjadi kolaborator efektif; dan (5) menjadi motivasi intrinsik bagi pebelajar untuk belajar.

Hal ini sesuai dengan pernyataan Kono (2016), yang menyatakan bahwa PBL merupakan salah satu model pembelajaran yang menuntut aktivitas mental peserta didik untuk memahami suatu konsep pembelajaran, melalui situasi dan masalah yang disajikan pada awal pembelajaran. Dengan tujuan untuk melatih peserta didik menyelesaikan masalah dengan menggunakan pendekatan pemecahan masalah.

Penerapan keterampilan pemecahan masalah dalam kegiatan pembelajaran diharapkan agar peserta didik mampu bersaing di era globalisasi serta mampu memanfaatkaan kemajuan teknologi dengan pemecahan masalah pada dasarnya adalah belajar menggunakan metodemetode ilmiah atau berpikir secara sistematis, logis, teratur, dan teliti (Bahri dkk, 2018). Dengan memberikan permasalahan-permasalahan yang faktual yang dekat dengan kehidupan seharihari, maka peserta didik akan dilatih untuk mengasah kemampuan mereka dalam mengkritisi sebuah permasalahan secara mendalam dan mampu memberikan solusi yang tepat bagi permasalahan yang diberikan(Titin \& Yokhebed, 2018).

Adanya pengaruh penerapan model PBL terhadap kemampuan pemecahan masalah siswa disebabkan oleh tahap kegiatan pembelajaran dari model PBL. Dalam model PBL tahap pertama adalah orientasi masalah kepada siswa. Tahap ini merupakan tahap yang paling penting untuk dilakukan agar kemampuan pemecahan masalah siswa menjadi tinggi, karena apabila guru tidak dapat mengorientasikan masalah dengan baik dan benar kepada siswa, maka tahap-tahap selanjutnya secara otomatis tidak akan berjalan dengan maksimal (Hilda dkk,2019).

Hasil observasi awal di SMA Negeri 3 Makassar menunjukkan bahwa proses pembelajaran masih berpusat pada guru (teacher oriented), karena proses pembelajaran di dalam kelas masih menggunakan model pembelajaran konvensional dengan metode ceramah. Dalam kondisi seperti ini, kesempatan siswa untuk menemukan dan membangun pengetahuannya sendiri hampir tidak ada, karena guru aktif sendiri menjelaskan apa yang telah disiapkannya sehingga siswa hanya menerima saja apa yang disampaikan oleh guru dan membuat siswa cenderung pasif pada saat pembelajaran.

Mata pelajaran Biologi dikembangkan melalui kemampuan berpikir analitis, induktif, dan deduktif untuk menyelesaikan masalah yang berkaitan dengan peristiwa alam sekitar. Salah satu materi yang cocok digunakan melihat peningkatan kemampuan pemecahan masalah adalah materi Perubahan lingkungan. PBL merupakan salah satu model pembelajaran yang menuntut siswa untuk terlibat aktif di dalam proses pembelajaran untuk melatih siswa untuk menerapkan langkah-langkah pemecahan masalah yang dapat digunakan untuk mencari jalan keluar suatu permasalahan (Rosmawari dkk, 2012).

Hal ini sangat sesuai untuk menjawab kebutuhan di SMA Negeri 3 Makassar dimana keaktifan siswa dalam proses pembelajaran masih rendah karena pembelajaran fokus terhadap guru, bukan siswa. Rendahnya keaktifan siswa dalam proses pembelajaran diperkirakan mempengaruhi kemampuan pemecahan masalah dan hasil belajar siswa di sekolah ini.

Berdasarkan latar belakang masalah yang telah diuraikan di atas, maka rumusan masalah dalam penelitian ini adalah: (1) Bagaimana kemampuan pemecahan masalah peserta didik 
dengan menerapkan model pembelajaran berbasis masalah PBL pada pembelajaran Biologi kelas X SMA Negeri 3 Makassar? (2) Adakah pengaruh penerapan model PBL terhadap kemampuan pemecahan masalah peserta didik pada pembelajaran Biologi kelas X SMA Negeri 3 Makassar?

\section{Metode Penelitian}

Jenis penelitian ini adalah quasi experimental (eksperimen semu) dengan desain penelitian pre test-post test control group design yang bertujuan untuk mengetahui pengaruh penerapan model Problem Based Learning (PBL) terhadap kemampuan pemecahan masalah dan hasil belajar biologi peserta didik kelas X SMA Negeri 3 Makassar.

Penelitian ini dilaksanakan di SMA Negeri 3 Makassar pada bulan April 2019. Populasi dalam penelitian ini adalah seluruh siswa kelas X MIA SMA Negeri 3 Makassar semester genap Tahun Ajaran 2018/2019, sedangkan pengambilan sampel dilakukan dengan teknik random sampling sehingga terpilih kelas X MIA 1 sebagai kelas eksperimen dan kelas X MIA 5 sebagai kelas kontrol. Variabel bebas dalam penelitian ini adalah model Problem Based Learning (PBL) dan model pembelajaran konvensional sementara variabel terikat adalah kemampuan pemecahan masalah

Teknik pengumpulan data yang digunakan dalam penelitian ini adalah: (1) tes uraian untuk mengukur kemampuan pemecahan masalah. Teknik analisis data yang digunakan yaitu analisis statistik deskriptif dan statistik inferensial dengan menggunakan uji analisis kovarian (anacova) pada program SPSS versi 22.0.

\section{Hasil dan Pembahasan}

a. Analisis Statistik Deskriptif

1) Kemampuan Pemecahan Masalah Biologi Peserta didik Kelas X SMA Negeri 3 Makassar

Tabel 1. Nilai Kemampuan Pemecahan Masalah Biologi Peserta Didik Kelas X SMA Negeri 3 Makassar

\begin{tabular}{|c|c|c|c|c|}
\hline \multirow{2}{*}{ Statistik } & \multicolumn{2}{|c|}{ Model PBL } & \multicolumn{2}{c|}{ Model Konvensional } \\
\cline { 2 - 5 } & Pretest & Posttest & Pretest & 32 \\
\hline Jumlah Sampel (N) & 32 & 32 & 32 & 58,53 \\
\hline Rata-Rata & 42,73 & 78,44 & 36,17 & 10,117 \\
\hline Standar Deviasi & 7,630 & 8,884 & 6,318 & 40 \\
\hline Nilai Minimum & 28 & 63 & 25 & 75 \\
\hline Nilai Maksimum & 53 & 95 & 53 & 1873 \\
\hline Jumlah & 1368 & 2510 & 1158 & \\
\hline
\end{tabular}

Tabel 1 menunjukan deskripsi nilai kemampuan pemecahan masalah model PBL dan model Konvensional pada materi perubahan lingkungan peserta didik kelas X SMA Negeri 3 Makassar. Nilai rata-rata kemampuan pemecahan masalah siswa mengalami peningkatan setelah proses pembelajaran, baik pada model PBL dan model konvensioanal. Namun jika ditinjau dari nilai kedua kelompok tersebut, kelompok yang dibelajarkan dengan menerapkan model PBL memiliki nilai rata-rata yang lebih tinggi dibandingkan dengan kelompok dibelajarkan dengan menerapkan model pembelajaran konvensional. 
Tabel 2. Distribusi Frekuensi dan Persentase Kategori Kemampuan Pemecahan Masalah Biologi Peserta didik Kelas X SMA Negeri 3 Makassar

\begin{tabular}{|c|c|c|c|c|c|c|c|c|c|}
\hline \multirow{2}{*}{ Kategori } & \multirow{2}{*}{ Interval } & \multicolumn{4}{|c|}{ Model PBL } & \multicolumn{4}{c|}{ Model Konvensional } \\
\cline { 3 - 10 } & & \multicolumn{2}{|c|}{ Pre Test } & \multicolumn{2}{|c|}{ Post Test } & \multicolumn{2}{c|}{ Pre Test } & \multicolumn{2}{c|}{ Post Test } \\
\cline { 3 - 10 } & & $\mathrm{F}$ & $\%$ & $\mathrm{~F}$ & $\%$ & $\mathrm{~F}$ & $\%$ & $\mathrm{~F}$ & $\%$ \\
\hline Sangat Baik & $80-100$ & 0 & 0,00 & 14 & 43,75 & 0 & 0,00 & 0 & 0,00 \\
\hline Baik & $65-79,99$ & 0 & 0,00 & 16 & 50,00 & 0 & 0,00 & 10 & 31,25 \\
\hline Cukup & $55-64,99$ & 0 & 0,00 & 0 & 0,00 & 0 & 0,00 & 10 & 31,25 \\
\hline Kurang & $40-54,99$ & 21 & 65,62 & 0 & 0,00 & 10 & 31,25 & 12 & 37,05 \\
\hline Sangat Kurang & $0-39,99$ & 11 & 34,37 & 0 & 0,00 & 22 & 68,75 & 0 & 0,00 \\
\hline
\end{tabular}

Tabel 2 menunjukkan frekuensi dan persentase kategori kemampuan pemecahan masalah kelompok eksperimen dan kelompok kontrol pada materi perubahan lingkungan siswa kelas $\mathrm{X}$ SMA Negeri 3 Makassar. Kemampuan pemecahan masalah siswa sebelum pembelajaran pada kelompok PBL dan Konvensional sama-sama didominasi oleh kategori kurang dan sangat kurang. Pada kelompok eksperimen dari 32 orang siswa, terdapat 21 orang siswa $(65,620, \%)$ pada kategori kurang, 11 orang siswa $(34,37 \%)$ dalam kategori sangat kurang. Pada kelompok kontrol dari 32 orang siswa, terdapat 10 orang siswa (31,25\%) berada dalam kategori cukup, 22 orang siswa $(68,75 \%)$ berada dalam kategori kurang sangat kurang.

Sedangkan kemampuan pemecahan masalah siswa setelah pembelajaran kedua kelompok sangat berbeda, dimana kdidominasi oleh kategori baik dan sangat baik sedangkan kelompok kontrol didominasi oleh kategori baik, cukup, dan kurang. Pada kelompok eksperimen dari 32 orang siswa, terdapat 14 orang siswa $(43,75 \%)$ berada dalam kategori sangat baik, dan 16 orang siswa $(50,00 \%)$ berada dalam kategori baik. Pada kelompok kontrol dari 32 orang siswa, terdapat 10 orang siswa $(31,25 \%)$ berada dalam kategori baik, 10 orang siswa $(31,25 \%)$ dalam kategori cukup, dan 12 orang siswa $(37,05 \%)$ dalam kategori kurang.

b. Analisis Statistik Inferensial

1) Uji Normalitas

a) Kemampuan Pemecahan Masalah Biologi Peserta Didik Kelas X SMA Negeri 3 Makassar

Tabel 3. Hasil Uji Normalitas Kemampuan Pemecahan Masalah Biologi Peserta Didik Kelas X SMA Negeri 3 Makassar

\begin{tabular}{|c|c|c|}
\hline Variabel & Sig. & Keterangan \\
\hline Pre Test Model PBL & 0,097 & Berdistribusi Normal \\
\hline Pre Test Model Pembelajaran Konvensional & 0,199 & Berdistribusi Normal \\
\hline Post Test Model PBL & 0,194 & Berdistribusi Normal \\
\hline Post Test Model Pembelajaran Konvensional & 0,147 & Berdistribusi Normal \\
\hline
\end{tabular}


Tabel 3 menunjukkan data kemampuan pemecahan masalah biologi peserta didik kelas X SMA Negeri 3 Makassar kelas yang dibelajarkan dengan menerapkan model PBL dan model pembelajaran konvensional, dimana semua variabel menunjukkan nilai signifikansi lebih besar daripada $\alpha=0,05$ sehingga dapat disimpulkan bahwa data berasal dari populasi yang berdistribusi normal.

2) Uji Homogenitas

a) Kemampuan Pemecahan Masalah Biologi Pesrta Didik Kelas X SMA Negeri 3 Makassar

Tabel 4. Hasil Uji Homogenitas Kemampuan Pemecahan Masalah Biologi Kelas X SMA Negeri 3 Makassar

\begin{tabular}{|c|c|c|}
\hline Variabel & Sig. & Keterangan \\
\hline Pre Test Kemampuan Pemecahan Masalah & 0,239 & Homogen \\
\hline Post Test Kemampuan Pemecahan Masalah & 0,273 & Homogen \\
\hline
\end{tabular}

Tabel 4 menunjukkan hasil uji homogenitas kemampuan pemecahan masalah biologi kelas X SMA Negeri 3 Makassar kelas yang dibelajarkan dengan menerapkan model PBL dan model pembelajaran konvensional, dimana semua variabel menunjukkan nilai signifikansi lebih besar daripada $\alpha=0,05$ sehingga dapat disimpulkan bahwa data kemampuan pemecahan masalah kedua kelas homogen.

3) Uji Hipotesis

a) Kemampuan Pemecahan Masalah Biologi Peserta Didik Kelas X SMA Negeri 3 Makassar

Tabel 5. Hasil Uji Hipotesis Pengaruh Model PBL Terhadap Kemampuan Pemecahan Masalah Biologi Peserta Didik KelasX SMA Negeri 3 Makassar

\begin{tabular}{|c|c|c|c|c|c|}
\hline Hasil & $\begin{array}{c}\text { Jumlah } \\
\text { Kuadrat Tipe } \\
\text { III }\end{array}$ & df & $\begin{array}{c}\text { Rata-rata } \\
\text { Kuadrat }\end{array}$ & F & Sig. \\
\hline Model Terkoreksi & $20626,318^{a}$ & 2 & 10313,159 & $\begin{array}{c}158,38 \\
7\end{array}$ & 0,000 \\
\hline Intersep & 10477.882 & 1 & 10477,882 & $\begin{array}{c}160,91 \\
7\end{array}$ & 0,000 \\
\hline Kemampuan Pemecahan Masalah & 44708,840 & 1 & 44708,840 & $\begin{array}{c}608,58 \\
2\end{array}$ & 0,000 \\
\hline Kelas & 20599,404 & 1 & 20599,404 & $\begin{array}{c}316,36 \\
0\end{array}$ & 0,000 \\
\hline Total & 346730,000 & 66 & & & \\
\hline Total Terkoreksi & 3406,673 & 65 & & & \\
\hline
\end{tabular}

Tabel 5 menunjukkan hasil uji hipotesis pengaruh model PBL terhadap kemampuan pemecahan masalah Masalah BiologiPeserta Didik KelasX SMA Negeri 3 Makassar, dimana diperoleh nilai signifikansi sebesar $0,000<0,05$ yang berarti $\mathrm{H}_{0}$ ditolak dan $\mathrm{H}_{1}$ diterima, sehingga dapat disimpulkan bahwa terdapat pengaruh model PBL terhadap kemampuan pemecahan masalah Masalah Biologi Peserta Didik KelasX SMA Negeri 3 Makassar.

Berdasarkan data hasil penelitian, terdapat pengaruh Kemampuan pemecahan masalah dan hasil belajar peserta didik yang dibelajarkan menggunakan Model PBL pada materi perubahan lingkungan kelas X MIA SMA Negeri 3 Makassar. Berdasarkan hasil anakova pada taraf kepercayaan 95\% $(\alpha=0,05)$ diperoleh nilai signifikansi 0,000 lebih kecil dari pada 0,05 $(\alpha<0,05)$, berarti $\mathrm{H}_{0}$ ditolak dan $\mathrm{H}_{1}$ diterima, sehingga dapat dikatakan bahwa ada pengaruh model PBL terhadap kemampuan pemecahan masalah materi perubahan lingkungan siswa kelas X SMA Negeri 3 Makassar. Skor rata-rata kemampuan pemecahan masalah kelompok eksperimen yang 
dibelajarkan dengan model PBL meningkat sebesar 38,63 poin sementara kelompok kontrol yang dibelajarkan dengan model pembelajaran konvensional hanya meningkat sebesar 22,35 poin.

Hasil yang didapatkan dari penelitian ini sejalan dengan penelitian sebelumnya oleh Handayani (2017) yang menunjukkan bahwa setelah dilakukan perlakuan yang berbeda antara model PBL dengan model pembelajaran konvensional terhadap kemampuan pemecahan masalah siswa mempunyai perbedaan yang signifikan yaitu model PBL lebih berpengaruh dan lebih baik dari model pembelajaran konvensional.

Proses pembelajaran tidak lagi terpusat pada guru, melainkan pada masing-masing peserta didik. PBL merupakan suatu pendekatan pembelajaran dimana peserta didik dilatih mengembangkan keterampilan berpikir tingkat tinggi, mengembangkan kemandirian, dan percaya diri. Selain itu, PBL melatih mahasiswa mengidentifikasi permasalahan yang terdapat dalam suatu wacana "yang disajikan". Sebagaimana disebutkan oleh Tan (2004) bahwa tujuan PBL adalah menjadikan peserta didik mahir dalam keterampilan proses dan keterampilan pemecahan masalah, memfasilitasi peserta didik(Palennari \& Lodang, 2018)

Hal ini sesuai dengan pernyataan Kono (2016), yang menyatakan bahwa PBL merupakan salah satu model pembelajaran yang menuntut aktivitas mental peserta didik untuk memahami suatu konsep pembelajaran, melalui situasi dan masalah yang disajikan pada awal pembelajaran. Dengan tujuan untuk melatih peserta didik menyelesaikan masalah dengan menggunakan pendekatan pemecahan masalah. Dengan memberikan permasalahan-permasalahan yang faktual yang dekat dengan kehidupan sehari-hari, maka peserta didik akan dilatih untuk mengasah kemampuan mereka dalam mengkritisi sebuah permasalahan secara mendalam dan mampu memberikan solusi yang tepat bagi permasalahan yang iberikan. Pembelajaran berbasis masalah merupakan pembelajaran yang didasarkan pada permasalahan. Masalah dijadikan titik awal untuk meningkatkan kemampuan pemecahan masalah peserta didik (Bahri dkk, 2018)

Adanya pengaruh penerapan model PBL terhadap kemampuan pemecahan masalah siswa disebabkan oleh tahap kegiatan pembelajaran dari model PBL. Dalam model PBL tahap pertama adalah orientasi masalah kepada siswa. Tahap ini merupakan tahap yang paling penting untuk dilakukan agar kemampuan pemecahan masalah siswa menjadi tinggi, karena apabila guru tidak dapat mengorientasikan masalah dengan baik dan benar kepada siswa, maka tahap-tahap selanjutnya secara otomatis tidak akan berjalan dengan maksimal (Oktaviani \& Tari, 2018)

Dalam model PBL tahap pertama adalah orientasi masalah kepada siswa. Tahap ini merupakan tahap yang paling penting untuk dilakukan agar kemampuan pemecahan masalah siswa menjadi tinggi, karena apabila guru tidak dapat mengorientasikan masalah dengan baik dan benar kepada siswa, maka tahap-tahap selanjutnya secara otomatis tidak akan berjalan dengan maksimal.

Tahap selanjutnya yaitu guru membantu peserta didik untuk mendefiniskan dan mengorganisikan tugas-tugas yang terkait dengan permasalahan. Pada tahap ini indikator pemecahan masalah yang terlatih adalah mengidentifikasi asumsi. Yamin(2011) mengatakan bahwa dalam Proses belajar yang dimulai dengan merumuskan masalah kemudian mencari, menyelidiki dan menemukan sendiri jawaban dari suatu masalah.

Tahap PBL yang ketiga adalah siswa melakukan penyelidikan individual maupun kelompok yang dibimbing oleh guru. Pada tahap ini indikator mengobservasi dan mempertimbangkan hasil observasi terlatihkan pada peserta didik. Kemampuan pemecahan masalah peserta didik lebih berkembang melalui pencarian sumber atau informasi yang relevan dengan rumusan masalah dan hipotesis yang dibuat. Pemecahan masalah tersebut memfasilitasi mahasiswa untuk berpikir. Keterampilan berpikir yang dimiliki mahasiswa tidak hanya sekedar menjawab pertanyaan tetapi dikaitkan dengan hipotesis yang dirumuskan(Palennari \& Lodang, 2018) Proses pencarian informasi atau sumber yang relevan melalui proses investigasi teoritik dari keterampilan pemecahan masalah. Investigasi informasi yang relevan terkait dengan hipotesis yang diajukan akan memberikan kemampuan kepada peserta didik untuk menemukan sendiri jawaban. 
Pada tahap mengembangkan dan menampilkan hasil karya. Indikator pemecahan masalah yang terlatihkan adalah memutuskan tindakan. Pada tahap ini peserta didik telah menentukan suatu tindakan yang tepat dalam menanggapi permasalah yang ada. Tindakan yang diambil peserta didik telah berdasarkan pertimbangan dengan berpikir logis dan rasional dalam bentuk membandingkan, mengklasifikasikan, menunjukkan interaksi sebab-akibat, kemampuan memberikan analogi serta mengkritisi informasi yang diperoleh yang semuanya bermuara pada kemampuan pemecahan masalah, Kemampuan pemecahan masalah dipandang sebagai bagian fundamental dari pembelajaran sains (Gok \& Silay ,2010] kemampuan siswa menggunakan informasi yang ada untuk menentukan apa yang harus dikerjakan dalam suatu keadaan tertentu. Kemampuan pemecahan masalah mengacu pada upaya yang diperlukan siswa dalam menentukan solusi atas masalah yang dihadapi.

Pada tahap terakhir yaitu menganalisis dan mengevaluasi proses pemecahan masalah. Pada tahap ini peserta didik dilatih untuk mengevaluasi hasil dari teman yang lain dan dilatih untuk membuat sebuah kesimpulan dari materi yang telah diajarkan. (Burris, S., \& Garton, 2007) Dalam membuat sebuah kesimpulan siswa akan melibatkan aspek dalam berpikir yaitu berpikir logis, proses induktif, deduktif, evaluative, memberikan argument yang logis dalam pengambilan keputusan. Seluruh aspek tersebut terakomodasi dalam diskusi interaktid saat masing-masing kelompok menyampaikan hasil pengamatan dan diskusinya. Guru dan siswa akan melakukan refleksi terhadap proses kegiatan pembelajaran guna memperbaiki dan menyempurnakan kegiatan pembelajaran berikutnya.

Berdasarkan hasil analisis data yang dilakukan dan juga dengan melihat kategori kemampuan pemecahan masalah Polya (1973), tahap menyelesaikan masalah dengan menerapkan model PBL adalah tahap dimana nilai yang diperoleh siswa didominasi oleh nilai yang tinggi jika dibandingkan dengan nilai langkah pemecahan masalah yang lain. Hal ini disebabkan karena PBL membantu siswa untuk mengembangkan keterampilan berpikir dan keterampilan mengatasi masalah, menjadi pebelajar yang mandiri, melatih siswa untuk mengembangkan dan mendalami permasalahan dengan meningkatkan kesadaran mereka mengenai cara yang berbeda dalam berpikir untuk penyelesaian pada suatu masalah (Tan, 2003).

Tingginya nilai kemampuan pemecahan masalah peserta didik yang dibelajarkan dengan model PBL tentu tidak lepas dari keunggulan model tersebut. PBL dapat mengembangkan dan meningkatkan kemampuan pemecahan masalah. PBL didasarkan pada premis bahwa situasi

bermasalah yang membingungkan atau tidak jelas akan mengembangkan rasa ingin tahu

pebelajar sehingga membuat mereka tertarik untuk menyelidiki. Masalah-masalah yang demikian banyak ditemukan dalam subject matter biologi misalnya pencemaran lingkungan (Palennari, 2011).

Model pembelajaran PBL terbukti secara signifikan dapat meningkatkan kemampuan pemecahan masalah peserta didik. Namun, ada beberapa hal yang harus diperhatikan dalam penerapan model pembelajaran berbasis masalah. Model pembelajaran konvensional tidak meningkatkan kemampuan pemecahan, Hal ini disebabkan karena guru di kelas mengajar dengan metode ceramah, dimana pada kondisi seperti ini kesempatan siswa untuk menemukan dan membangun pengetahuannya sendiri hampir tidak ada, karena guru aktif sendiri menjelaskan apa yang telah disiapkannya sehingga siswa hanya menerima saja apa yang disampaikan oleh guru.

\section{Kesimpulan}

Berdasarkan hasil penelitian dan pembahasan, maka kesimpulan yang dapat ditarik dalam penelitian ini adalah: (1) kemampuan pemecahan masalah biologi peserta didik siswa kelas X SMA Negeri 3 Makassar setelah diajarkan dengan model PBL berada pada kategori baik dan model konvensional berada pada kategori kurang, dengan nilai rata-rata pada model yang dibelajarkan dengan model PBL 78,44 dan model konvensional 58,53 (2) ada pengaruh 
penerapan model PBL terhadap kemampuan pemecahan masalah biologi peserta didik kelas X SMA Negeri 3 Makassar.

\section{Referensi}

Aisyah, S. (2015). Perkembangan Peserta Didik dan Bimbingan Belajar. Yogyakarta. Penerbit Deepublish.

Aunurrahman. (2010). Belajar dan Pembelajaran. Bandung. Alfabeta.

Anggraeni, R.., \& Herdiman. I. (2018). Kemampuan Pemecahan Masalah Matematik Siswa SMP pada Materi Lingkaran Berbentuk Soal Kontekstual Ditinjau dari Gender. Jurnal Numeracy, 5 (1), 19-28.

Bahri, A. (2017). Strategi Problem-Based Learning (PBL) Terintegrasi Reading Questioning and Answering (RQA) Meningkatkan Retensi Mahasiswa Berkemampuan Akademik Berbeda. MIPA Open \& Exposition. 68-75.

Bahri, A., Putriana., D. Irma Suryani Idris. (2018). Peran PBL dalam Meningkatkan Keterampilan Pemecahan Masalah Biologi. Jurnal Sainsmat. VII (2), 114-124

Fallis, A. (2013). Journal of Chemical Information and Modeling. 53 (9), 1689-1699.

Febriyanti, Chatarina. Irawan, Ari. (2017). Meningkatkan Kemampuan Pemecahan Masalah Dengan Pembelajaran Matematika Realistik. Jurnal Matematika dan Pendidikan Matematika. 6 (1)

Haling, A. (2007). Belajar dan Pembelajaran. Makassar: Badan Penerbit: Universitas Negeri Makassar.

Harnitayasri., Nurhayati., Irma Suryani. (2015). Efektivitas Model Pembelajaran Problem Based Learning (PBL) Terhadap Hasil Belajar Biologi Siswa Pada Materi Pencemaran Lingkungan di Kelas X. SMA NEGERI 2 POLEWALI. Jurnal Bionature. 16 (2), 103-109.

Hilda, K., Sutarni, Muhiddin P. (2019). Profil Efikasi diri Peserta didik berdasarkan Hasil belajar Biologi Kelas X Mia MAN 1 Makassar. Jurnal Biology Teaching. 2 (1)

Nasution, M. A. (2009). Kurikulum dan Pengajaran. Jakarta. PT.Bumi Aksara.

National Education Association. (2002). Audiovisual Instruction Department, New. Media and College Teaching. Washington. D.C. NEA.

Palennari, M. (2011). Potensi Startegi Integrasi Problem Based Learning dengan Pembelajaran Kooperatif Jigsaw dalam Meningkatkan Pemahaman Konsep Mahasiswa. Jurnal ilmiah Pendidikan Biologi. Biologi Edukasi. 3 (2), 26-33.

Palenari, M. (2013). Potensi Integrasi Problem Based Learning dengan Pembelajaran Kooperaif Jigsaw dalam Meningkatkan Ketersmpilsn Berpikir Mahasiswa. Jurnal Bionature. 13 (1), 19. 
Palennari, M., Hamka, L., Faisal. (2015). Pengembangan Rencana Pelaksanaan Perkuliahan Berorientasi Problem Based Learning Untuk Meningkatkan Keterampilan Bepirkir Kritis Mahasiswa. Jurnal Bionature. 16 (2), 69-76.

Peraturan Menteri Pendidikan dan Kebudayaan No.64. (2013) Standar Isi Pendidikan Dasar dan Menengah. Jakarta.

Permendikbud No 21. (2016). Standar Isi Pendidikan Dasar dan Menengah. Jakarta.

Rosmawati, Sri Elniati, Dewi Murni. (2012). Kemampuan Pemecahan Masalah dan Lembar Kegiatan Siswa Berbasis Problem Solving. FMIPA Universitas Negeri Makassar.

Tan, O. S. (2003). Problem Based-Learning Innovation: Using Problems to Power Learning in the 21st Century. Singapore. Cengage Learning Asia Pte Ltd.

Titin, T., \& Yokhebed, Y. (2018). Peningkatan Keterampilan Pemecahan Masalah (Problem Solving) Calon Guru Biologi Melalui Pembelajaran Berbasis Kearifan Lokal. Jurnal Pendidikan Matematika Dan IPA. 9(1), 77. https://doi.org/10.26418/ipmipa.v9i1.23701.

Tilaar, H.A.R. (1999). Beberapa Agenda Reformasi Pendidikan Nasional, Dalam Perspektif Abad 21. Tera Indonesia. Magelang.

Trianto. (2011). Mendesain model pembelajaran inovatif-progresif: konsep, landasan dan implementasinya pada kurikulum tingkat satuan pendidik, (KTSP). Kencana Prenada Media Group.

Trilling, B., \& Fadel, C. (2010). 21st Century Skills: Learning for Life in Our Times. San Francisco, CA. John Wiley \& Sons.

\begin{tabular}{|l|l|}
\hline Anisatya Amaliah & $\begin{array}{l}\text { Mahasiswa Jurusan Biologi, Fakultas Matematika dan Ilmu } \\
\text { Pengetahuan Alam, Universitas Negeri Makassar } \\
\text { E-mail: tyamaliah@gmail.com }\end{array}$ \\
\hline Muh Wiharto & $\begin{array}{l}\text { Dr. Ir, M.Si. Dosen Jurusan Biologi, Fakultas Matematika dan Ilmu } \\
\text { Pengetahuan Alam, Universitas Negeri Makassar } \\
\text { E-mail: } \text { wiharto09@gmail.com }\end{array}$ \\
\hline Muhiddin Palennari & $\begin{array}{l}\text { Dr. S. Pd, M.Pd. Dosen Jurusan Biologi, Fakultas Matematika dan } \\
\text { Ilmu Pengetahuan Alam, Universitas Negeri Makassar } \\
\text { E-mail: } \text { muhiddin.p@unm.ac.id }\end{array}$ \\
\hline
\end{tabular}

